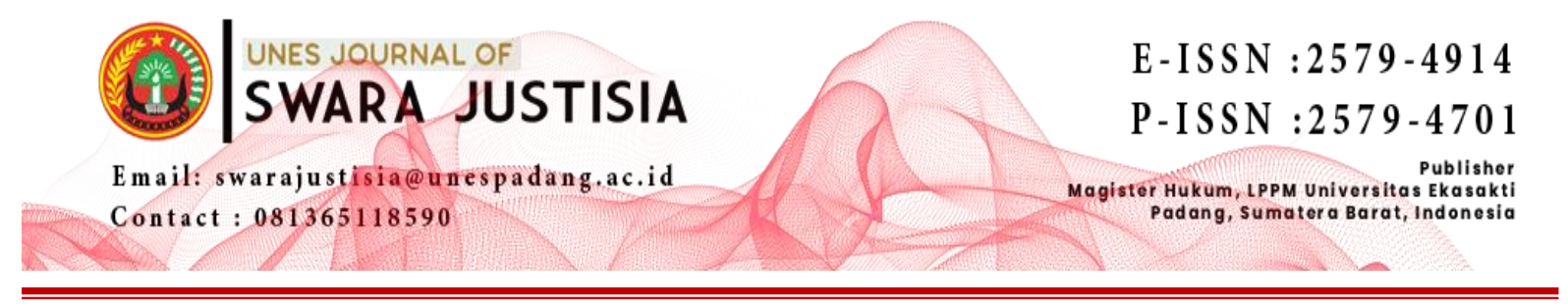

\title{
PENYIDIKAN TINDAK PIDANA PENYALAHGUNAAN GAS ELPIJI BERSUBSIDI PADA SATUAN RESERSE KRIMINAL POLRES SAWAHLUNTO
}

\author{
Danu Aryadi \\ Program Magister Ilmu Hukum, Universitas Ekasakti, Padang, Indonesia \\ Email: aryadidanu@yahoo.com
}

\begin{abstract}
The crime of misuse of three kilogram LPG gas that occurred in the Sawahlunto district police jurisdiction, as in the police report LP/2/SPKT-A/2018/Res Swl, this crime includes the misuse of three kilogram LPG in the case of abuse in the field of supply and distribution . Although this matter has been regulated in the legislation namely Law No. 22 of 2001 concerning Oil and Gas, Minister of Energy and Mineral Resources Regulation No. 26 of 2009 concerning the Provision and Distribution of Liquefied Petroleum Gas, 3 Kilogram Republic of Indonesia Presidential Regulation Number 104 of 2007 concerning Provision, Distribution and Pricing of Liquefied Petroleum Gas 3 Kilograms. As for the unlawful act taking place in the Sawahlunto area, the law enforcement of the perpetrators of the abuse of the three kilogram LPG is handled by the Sawahlunto Regional Police Criminal Unit.
\end{abstract}

Keywords: Investigation, Abuse, Elpiji Gas Subsidized

\begin{abstract}
ABSTRAK
Kejahatan penyalahgunaan gas LPG tiga kilogram yang terjadi di wilayah hukum kepolisian kabupaten Sawahlunto, seperti dalam laporan polisi LP/2/SPKT-A/2018/Res Swl, kejahatan ini termasuk penyalahgunaan tiga kilogram LPG dalam kasus penyalahgunaan di bidang penawaran dan distribusi. Meskipun hal ini telah diatur dalam undang-undang yaitu UU No. 22 tahun 2001 tentang Minyak dan Gas Bumi, Peraturan Menteri Energi dan Sumber Daya Mineral No. 26 tahun 2009 tentang Penyediaan dan Distribusi Gas Bumi Cair, 3 Kilogram Peraturan Presiden Republik Indonesia Nomor 104 tahun 2007 tentang Penyediaan, Distribusi, dan Penetapan Harga Gas Minyak Cair 3 Kilogram. Adapun tindakan melanggar hukum yang terjadi di daerah Sawahlunto, penegakan hukum pelaku pelecehan LPG tiga kilogram ditangani oleh Unit Kriminal Kepolisian Daerah Sawahlunto.
\end{abstract}

Kata Kunci: Investigasi, Penyalahgunaan, Elpiji Gas Bersubsidi

\section{PENDAHULUAN}

Minyak dan gas bumi merupakan sumber daya alam strategis tidak terbarukan yang dikuasai oleh negara serta merupakan komoditas vital yang menguasai hajat hidup orang banyak dan mempunyai peranan penting dalam perekonomian nasional sehingga pengelolaannya harus dapat secara maksimal memberikan kemakmuran dan kesejahteraan rakyat. Dalam kegiatan usaha minyak dan gas bumi mempunyai peranan penting dalam 
memberikan nilai tambah secara nyata kepada pertumbuhan ekonomi nasional yang meningkat dan berkelanjutan.

Sistem Ketahanan Energi mengamanatkan bahwa kita harus mempunyai kemampuan untuk merespon dinamika, sehingga ketika ada sumber daya minyak yang berkurang maka sumber daya yang lain harus dikembangkan, pengaruh perubahan energi global yang mengisyaratkan harus dimulai energi bersih dan kemandirian untuk menjamin ketersediaan energi, dimana dari Sabang sampai Merauke semua warga negara berhak mendapatkan bahan bakar dalam memenuhi kehidupannya. ${ }^{1}$

Gas alam sering juga disebut sebagai gas bumi atau gas rawa, adalah bahan bakar fosil berbentuk gas yang terutama terdiri dari metana $(\mathrm{CH} 4)$. Metana dapat ditemukan di ladang minyak, ladang gas bumi dan juga tambang batu bara. Ketika gas yang kaya dengan metana diproduksi melalui pembusukan oleh bakteri anaerobik dari bahan-bahan organik selain dari fosil, maka ia disebut biogas.

Sumber biogas dapat ditemukan di rawa-rawa, tempat pembuangan akhir sampah.Gas elpiji merupakan bahan bakar yang telah banyak digunakan oleh masyarakat. Penggunaannya berawal dari Kebijakan Pemerintah Pada Tahun 2007, yaitu tentang konversi penggunaan minyak tanah ke gas elpiji (Liquid Petroleum Gas) yang selanjutnya disebut elpiji. Kebijakan ini berangkat dari upaya pemerintah dalam menghemat APBN dan mengingat cadangan minyak bumi yang menipis.

Liquified Petroleum Gas (LPG) diperkenalkan oleh Pertamina pada tahun 1968, ada beberapa varian kemasan Liquified Petroleum Gas (elpiji), yaitu dalam kemasannya dimana terdapat kemasan $3 \mathrm{~kg}, 12 \mathrm{~kg}, 16 \mathrm{~kg}, 50 \mathrm{~kg}$. Keberadaan tiga varian ini membawa dampak signifikan, hal ini antara lain dipicu terjadinya perpindahan konsumsi dari konsumen LPG 12 $\mathrm{kg}$ dan $50 \mathrm{~kg}$, ke LPG $3 \mathrm{~kg}$ yang didorong oleh fakta bahwa antar ketiga varian LPG tersebut dapat bersubstitusi satu dengan yang lain dengan proses yang sangat mudah.

Gas Elpiji 3 kilogram itu sendiri yang merupakan elpiji yang bersubsidi dan dikategorikan sebagai elpiji tertentu sebagaimana disebut dalam Pasal 1 Angka (9) Peraturan Menteri ESDM Nomor 26 Tahun 2009 tentang Penyediaan dan Pendistribusian Liquefied Petroleum Gas, yang berbunyi: “elpiji Tertentu adalah elpiji yang merupakan bahan bakar yang mempunyai kekhususan karena kondisi tertentu seperti pengguna atau penggunaannya, kemasannya, volume dan atau harganya yang masih harus diberikan subsidi”.

\section{METODE PENELITIAN}

Spesifikasi penelitian ini adalah penelitian yang bersifat deskriptif analistis, ${ }^{2}$ yaitu penelitian yang memberikan gambaran tentang Penyidikan Tindak Pidana Penyalahgunaan Gas Elpiji Tiga Kilogram Oleh Penyidik Polres Sawahlunto.Pendekatan utama yang digunakan dalam penelitan ini adalah pendekatan secara yuridis normatif dan di dukung dengan pendekatan secara yuridis empiris. Pendekatan yuridis normatif, dilakukan dengan melakukan penelitian terhadap aturan-aturan hukum yang terkait dengan permasalahan yang diangkat dalam penelitian ini. Sedangkan pendekatan yuridis empiris, dilakukan dengan melakukan penelitian lapangan untuk melihat bekerja aturan-aturan hukum tersebut dalam prakteknya di lapangan. Data yang digunakan dalam penelitian ini adalah data sekunder dan

\footnotetext{
${ }^{1}$ Undang-Undang Republik Indonesia Nomor 22 Tahun 2001 Tentang Minyak Dan Gas Bumi.

${ }^{2}$ Pedoman Penyusunan Usulan Penelitian dan Tesis, Universitas Ekasakti, Padang, 2017, hlm. 6
} 
data primer yang dikumpulkan melalui penelitian kepustakaan dan penelitian lapangan yang kumpulkan melalui studi kepustakaan dan wawancara. Data tersebut kemudian di analisis secara kualitatif dan disajikan dalam bentuk deskriptif kualitatif.

\section{HASIL DAN PEMBAHASAN}

\section{A. Penyidikan Tindak Pidana Penyalahgunaan Gas Elpiji Bersubsidi Pada Satuan Reserse Kriminal Polres Sawahlunto}

Proses awal dalam menyelesaikan perkara tindak pidana yakni dimulai dengan penyelidikan, penyidikan, tuntutan Jaksa Penuntut Umum, pemeriksaan dipersidangan dan pembuktian. Putusan Majelis Hakim Pengadilan Negeri ini berpijak pada hukum formal sekaligus materil. Dalam artian, aturan berupa undang-undang tersebut merupakan produk dari badan legislatif bersama eksekutif, dan isi dari undang-undang tersebut mengikat bagi pelaku tindak pidana apabila unsur-unsurnya terpenuhi.

Berdasarkan Analisa Kasus yang telah diuraikan tentang penyalahgunaan gas elpiji bersubsisidi 3 kilo gram terdapat petunjuk adanya tindak pidana menyalahgunakan pengangkutan dan atau niaga gas elpiji 3 kilo gram yang disubsidi pemerintah yang dilakukan oleh tersangka Yulisman Pgl. YUL karena terpenuhinya unsur-unsur sebagaimana yang dimaksud dalam Pasal 55 juncto Pasal 53 huruf (d) Undang-undang Republik Indonesia Nomor 22 Tahun 2001 tentang Minyak dan Gas Bumi juncto Pasal 55 Ayat (1) ke-1 KUHP yaitu sebagai berikut :

\section{Setiap orang.}

Unsur ini telah terpenuhi, berdasarkan keterangan para saksi, ditambahkan dengan keterangan tersangka Yulisman Pgl. YUL, maka sebagai subjek hukum yang dapat mempertanggung jawabkan perbuatannya adalah yulisman Pgl. YUL, Tempat/tanggal lahir Padang pada tanggal 04 Juli 1970, Umur 44 Tahun, Suku Caniago / Minang, Pekerjaan Swasta (Direktur Utama PT. Sumber Daya Prima), Agama Islam, Kebangsaan Indonesia, Alamat Cindakir RT/RW 003/003 Kelurahan Teluk Kabung Utara Kecamatan Bungus Teluk Kabung Kota Padang, alamat sekarang di perumahan Green Mutiara Kelurahan Cengkeh Kecamatan Rimbo Data Kota Padang.

\section{Menyalahgunakan pengangkutan.}

Unsur ini telah terpenuhi, bahwa pada Sabtu tanggal 20 April 2017 sekira pukul 01.00 Wib di Desa Santur Kecamatan Barangin Kota Sawahlunto telah terjadi tindak pidana penyalahgunaan pengangkutan dan/atau niaga elpiji 3 kilogram yang disubsidi pemerintah dengan menggunakan kendaraan merk MITSUBISHI, type FM517HS (4X2) M/T, Jenis Mobil Barang, mengangkutabung gas elpiji $3 \mathrm{~kg}$ sebanyak 200 tabung, dimana Tersangka Yulisman Pgl. YUL selaku pemilik PT. Sumber Daya Prima tempat kendaraan dan BBM tersebut berasal, mengeluarkan atau menerbitkan surat-surat/dokumen berupa Surat Pengantar Pengiriman berlogo Pertamina dan Surat Jalan dari PT. Sumber Daya Prima yang diterima/dikuasai oleh Jendriadi Sulaiman Pgl. JEN sebagai Sopir dari kendaraan tersebut dimana surat-surat/dokumen berupa Surat Pengantar Pengiriman berlogo Pertamina tersebut tidak ada dikeluarkan atau diterbitkan oleh PT. Prizaco Gasindo sebagai yang berhak mengeluarkan surat-surat/dokumen tersebut sesuai dengan keterangan saksi dari PT. Prizaco Gasindo, yang beralamatkan di Kav. NS-3 Kawasan Industri, Padang Desa Karang Tengah, Kec. Batang Anai, kab. Padang Pariaman, tentang 
Surat Pengantar Pengiriman berlogo Pertamina yang dibawa oleh Jendriadi Sulaiman Pgl. JEN dalam mengangkut tabung gas lepiji bersubsidi $3 \mathrm{~kg}$ tersebut adalah palsu karena setelah dilakukan pengecekan pada sistem yang terdapat di PT. Prizaco Gasindo, kendaraan merk MITSUBISHI, type FM517HS (4X2) M/T, Jenis Mobil Barang, Model Tangki Nomor Polisi BA 8008 BU warna biru Kombinasi milik PT. Sumber Daya Prima pada tanggal 19 April 2017 tidak ada melakukan pengambilan elpiji 3 kilo gram ke PT. Prizaco Gasindo sesuai dengan keterangan staff yang sebagai saksi dari PT. Prizaco Gasindo.

\section{Niaga Bahan Bakar Minyak Yang Disubsidi Pemerintah.}

Unsur ini telah terpenuhi, dimana PT. Sumber Daya Prima milik tersangka Yulisman Pgl. YUL mengangkut untuk menjual gas elpiji $3 \mathrm{~kg}$ sebanyak lebih kurang 200 tabung ke CV. Tahiti akan tetapi di Surat Jalan tertulis PT. Yatikol, dimana keterangan saksi dan tersangka bahwa tabung gas elpiji 3 kilogram sebanyak 200 unit tabung tersebut berasal dari PT. Prizaco Gasindo. Dimana jenis tabung elpiji 3 kilogram, telah dinyatakan sebagai elpiji jenis tertentu atau bahan bakar bersubsidi aoleh pemerintah melalui peraturan perundang-undangan, sebagaiamana di atur dalam Pasal 1 Angka (2) Peraturan Bersama Menteri Dalam Negeri Dan Menteri Energi Dan Sumber Daya Mineral Tentang Pelaksanaan Pembinaan Dan Pengawasan Pendistribusian Tertutup Liquified Petroleum Gas Tertentu 01 Daerah, yang menyatakan bahwa LPG Tertentu Adalah LPG Tabung $3 \mathrm{Kg}$ Yang Merupakan Bahan Bakar Yang Mempunyai Kekhususan Karena Kondisi Tertentu Seperti Pengguna/Penggunaannya, Kemasannya, Volume Dan/Atau Harganya Yang Masih Harus Diberikan Subsidi.

\section{Tanpa izin usaha niaga.}

Unsur ini telah terpenuhi, dimana PT. Sumber Daya Prima milik tersangka Yulisman Pgl. YUL mengangkut untuk menjual gas elpiji bersubsidi sebanyak 200 unit tabung ke CV. Tahiti akan tetapi di Surat Jalan tertulis PT. YATIKOL sedangkan PT. Sumber Daya Prima milik tersangka Yulisman Pgl. YUL tidak memiliki izin usaha niaga, sesuai dengan keterangan saksi dari PT. Prizaco Gasindo dengan Jabatan Jr. Sales Excekutive yang bertugas dan bertanggung terhadap penyaluran gas elpiji menyatakan bahwa PT. Sumber Daya Prima milik tersangka Yulisman Pgl. YUL tidak memiliki izin untuk melakukan niaga gas elpiji baik subsidi maupun non subsidi, izin yang dimiliki oleh PT. Sumber Daya Prima milik tersangka Yulisman Pgl. YUL adalah sebagai Jasa Pengangkutan BBM Non Subsidi.

Berdasarkan pembahasan terhadap Fakta-fakta/bukti dalam analisa kasus dan analisa yuridis tersebut maka terhadap tersangka YULISMAN Pgl. YUL patut diduga keras telah melakukan perbuatan menyalahgunakan pengangkutan dan/atau niaga elpiji 3 kilogram yang disubsidi pemerintah. Oleh karena itu tersangka dapat disangkakan telah melakukan perbuatan menyalahgunakan pengangkutan dan/atau niaga elpiji 3 kilogram yang disubsidi pemerintah, sebagaimana yang dimaksud dalam Pasal 55 juncto Pasal 53 Huruf (d) Undang-undang Republik Indonesia Nomor 22 Tahun 2001 tentang Minyak dan Gas Bumi juncto Pasal 55 Ayat (1) Ke-1 KUHP.

Dalam penanganan perkara penyalahgunaan elpiji 3 kilogram yang di tangani oleh satuan reserse kriminal Polres Sawahlunto, dimana telah mengacu pada Peraturan Kapolri Nomor 14 Tahun 2012 tentang Manajemen Penyidikan Tindak Pidana. Dimana dalam melaksanakan tugas penegakan hukum, penyidik Kepolisian Negara Republik Indonesia 
mempunyai tugas, fungsi, dan wewenang di bidang penyidikan tindak pidana, yang dilaksanakan secara profesional, transparan, dan akuntabel terhadap setiap perkara pidana guna terwujudnya supremasi hukum yang mencerminkan rasa keadilan.

Manajemen Penyidikan adalah serangkaian kegiatan penyidikan yang meliputi perencanaan, pengorganisasian, pelaksanaan, pengawasan dan pengendalian dalam segala aspek yang terkait guna memproses suatu tindak pidana. Sehingga mendapatkan hasil sesuai tujuan dan efisiensi kinerja penyidik, dan dalam penanganan tindak pidana penyalahgunaan elpiji gas 3 kilogram telah melalui tahapan-tahapan sebagaimana di tentukan oleh peraturan perundang-undangan yang mana meliputi:

a. Penyelidikan yang di lakukan satreskrim polres sawahlunto telah melakukan pengintaian terhadap tempat penyimpanan tabung gas;

b. Penyidik telah melakukan pencegatan dan penangkapan terhadap pemilik dan sopir dari mobil truck yang membawa tabung dan gas elpiji yang bersubsidi tanpa di lengkapi dokumen yang sah tersebut;

c. Penyidikan yang mana telah memeriksa tersangka, saksi, mendapatkan keterangan ahli hingga menyita barang bukti berupa dokumen palsu dan unit kendaraan yang digunakan dalam melancarkan tindak pidana penyalahgunaan gas elpiji 3 kilogram.

d. Penahanan juga di lakukan oleh penyidik sebab dalam perkara tersebut penyidik berpendapat bahwa harus dilakukan penahanan terhadap pelaku mengingat di duga dapat memutus jaringan kejahatan, menghilangkan barang bukti dan di kawatirkan Tersangka akan melarikan diri.

\section{B. Kendala Yang Ditemui Oleh Penyidik Dalam Penyidikan Tindak Pidana Penyalahgunaan Gas Elpiji Tiga Kilogram Oleh Penyidik Polres Sawahlunto.}

Berdasarkan data dilapangan bahwa selama ini pihak kepolisian telah melakukan penanganan terhadap tindak pidana penyalahangunaan gas elpiji $3 \mathrm{~kg}$. Pihak satuan Kasat Reskrim Sawahlunto telah melakukan penangkapan terhadap pelaku penyalahgunaan gas elpiji, namun di dalam penanganan kasus ini pihak penyidikan masih mengalami berbagai kendala dalam mencari informasi yang diperoleh baik dari tersangka maupun dari saksi yang ada di lapangan. Hal ini juga disampaikan oleh Narasumber mengungkapkan bahwa dalam penanganan kasus ada kendala atau maslah yang timbul dalam proses penyidikan, hal tersebut tidak dapat dipungkiri bahwa tindakan penyidikan yang dilakukan oleh penyidik Polri terhadap tindak pidana itu bagaikan sebuah pabrik yang harus tetap beroperasi yang dengan segala dayanya pabrik itu berusaha sendiri melakukan pencarian bahan yang bisa diproduksi, memilah-milah bahan yang akan bisa diproduksi, mengolah atau mengolah bahan yang akan diproduksi. ${ }^{3}$

Meskipun dengan biaya atau cost yang sangat tidak mencukupi namun harus jadi dan harus siap terjual kepasaran umum yaitu kejaksaan, pengadilan, dan bahkan terhadap penasihat hukum, tersangka ataupun terdakwa bila diperlukan. Tindakan ini tidak semua orang dapat melakukannya walaupun tidak perlu dipungkiri kadang-kadang terbesit kabar yang tidak benar, tetapi saat ini sudah sangat berbeda, karena didalam lembaga internal kepolisian sendiri ada badan pengawas yang tidak bisa dajak kompromi

\footnotetext{
3. Wawancara dengan Iptu Syaiful Anwar, anggota KasatReskrim Polres Sawahlunto, Senin 25-02-2019, di Sawahlunto.
} 
apabila ada kesalahan anggota, dan harus diproses secara internal. Dilain pihak penyidik juga harus menanggungbiaya yang tidak diperlukan contohnya, tidak jarang penyidik harus digugat diperadilan perdata, sementara untuk peradilan perdata tidak ada anggaran untuk itu khususnya buat penyidik.

Permasalahan ketika proses hukum formil itu dioperasionalkan, serta hukum materil itu diaplikasikan dalam penanganan perkara, aplikasi hukum formil itu dimulai dari pemanggilan, pemeriksaan, penangkapan, penyitaan, penggeledahan, penahanan lanjutan, dan mengungkap kebutuhan materilnya. Mengungkap kebutuhan hukum materil tersebut misalnya pembuktian, kecermatan, dan ketelitian dalam pembuatan berita acara yang akan mempengaruhi kualitas pembuktian perkara itu sendiri .

Selanjutnya kendala yang utama dalam penyidikan tindak pidana penyalahgunaan gas elpiji 3 kilogram dapat dijabarkan sebagai berikut :

1. Peraturan perundang-undangan terkait khusus tentang peruntukan gas elpiji 3 kilogram masih belum rigid. Sehingga penyidik hanya dapat menjangkau penyalahgunaan pengangkutan saja. Sebab di dalam Peraturan Presiden Republik Indonesia Nomor 104 Tahun 2007 Tentang Penyediaan, Pendistribusian Dan Penetapan Harga Liquefied Petroleum Gas Tabung 3 Kilogram, pada Pasal 3 menyebutkan bahwa : "Penyediaan dan pendistribusian LPG Tabung $3 \mathrm{Kg}$ hanya diperuntukkan bagi rumah tangga dan usaha mikro ".Dalam hal definisi rumah tangga belum di buat klasifikasi yang jelas sehingga penggunaan elpiji 3 kilogram belum tepat penggunaan dan pemanfaatannya;

2. Banyaknya pihak dalam kejahatan penyalahgunaan elpiji 3 kilogram, sehingga proses pengungkapan kerap terhenti pada pelaku pengangkutannya saja.

3. Tidak dapatnya penyidik menjadikan Pemilik Restoran Sebagai pengguna Gas elpiji 3 kilogram sebagai tersangka di karenakan tidak cukup bukti yang menjerat para pemilik restoran dan saat di lakukan pemeriksaan terhadap restoran tidak di dapati tabung elpiji 3 kilogram atau barang bukti lain yang membuat si pemilik restoran menjadi tersangka dalam hal penyalah gunaan gas elpiji 3 kilogram yang di selidiki oleh Polres Sawahlunto.

4. Tidak dapatnya penyidik memanggil, menghadirkan dan membawa saksi dari pemilik Restoran yang di curigai akan menerima gas elpiji 3 kilogram tersebut dari tersangka di karenakan Saksi yang di maksud tidak ada di tempat dan tidak pernah terlihat lagi semenjak penagkapan terhadap Yulisman tersebut di lakukan.

5. Tidak dapatnya Penyidik menjadikan Pemilik (Asal mula) gas elpiji 3 kilogram tersebut sebagai tersangka di karenakan tersangka bungkam dan enggan mengatakan dari mana asal gas elpiji 3 kilogram yang di ambil dari Provinsi Jambi tersebut di dapat dan siapa yang menjual kepada para tersangka, dan saat di lakukan Berita Acara Pemeriksaan terhadap tersangka keterangan tersangka juga sering berubah-ubah mengenai siapa pemilik dari gas elpiji 3 kilogram tersebut.

6. Berkas perkara dari perkara tersebut di jadikan dua berkas / di Split di karenakan satu orang tersangka hanyalah sopir dan dapat di jadikan saksi dari tersangka lain dan di lakukan karena kurangnya saksi dari perkara tersebut.Pihak penyidik harus mendatangkan terlebih dahulu saksi ahli atau bahkan harus menyusul ke kantor saksi ahli terkait baik dari pihak pertamina maupun pihak lain yang mana membutuhkan 
waktu dan biaya mengingat wilayah sawahlunto jauh dari keberadaan para ahli untuk dapat dimintai keterangannya di samping itu proses tersebut membutuhkan banyak waktu sehingga mempengaruhi waktu pengungkapan tindak pidana penyalahgunaan elpiji 3 kilogram.

\section{KESIMPULAN DAN SARAN}

Penyidikan penyalahgunaan gas elpiji bersubsidi gas $3 \mathrm{~kg}$ yang dilakukan oleh Reserse Kriminal Polres Sawahlunto Dalam Kasus Laporan Polisi No: LP/2/SPKTA/2018/Polres Sawahlunto, dilakukan dengan langkah-langkah sebagai berikut dalam analisa kasus dan analisa yuridis tersebut maka terhadap tersangka Yulisman Pgl. YUL patut diduga keras telah melakukan perbuatan menyalahgunakan pengangkutan dan/atau niaga bahan bakar minyak yang disubsidi pemerintah yang mana telah terlebih dahulu di lakukan pengintaian terhadap tersangka oleh Penyidik. Penyidik juga mengamankan dokumendokumen palsu yang di bawa oleh tersangka, memeriksa beberapa orang saksi baik dari orang umum, saksi ahli maupun dari anggota di lapangan yang melakukan penangkapan. Oleh karena itu tersangka dapat disangkakan telah melakukan perbuatan menyalahgunakan pengangkutan dan/atau niaga bahan bakar minyak yang disubsidi pemerintah, sebagaimana yang dimaksud dalam Pasal 55 jo Pasal 53 huruf d Undang-undang Republik Indonesia Nomor 22 Tahun 2001 tentang Minyak dan Gas Bumi jo Pasal 55 Ayat (1) ke-1 KUHP dan untuk tersangka di lakukan penahanan oleh penyidik mengingat di duga dapat memutus jaringan kejahatan, menghilangkan barang bukti dan di kawatirkan tersangka melarikan diri.

Kendala yang dihadapi oleh Penyidik Dalam Penyidikan Tindak Pidana Penyalahgunaan Gas Elpiji Tiga Kilogram Oleh Penyidik Polres Sawahlunto adalah pihak penyidik harus mendatangkan terlebih dahulu saksi ahli terkait baik dari pihak pertamina maupun pihak lain yang mana membutuhkan waktu dan biaya mengingat wilayah sawahlunto jauh dari keberadaan para ahli untuk dapat dimintai keterangannya di samping itu proses tersebut membutuhkan banyak waktu sehingga mempengaruhi waktu pengungkapan tindak pidana penyalahgunaan elpiji 3 kilogram, Tidak dapatnya penyidik menjadikan Pemilik Restoran Sebagai pengguna Gas elpiji 3 kilogram sebagai tersangka di karenakan tidak cukup bukti yang menjerat para pemilik restoran dan saat di lakukan pemeriksaan terhadap restoran tidak di dapati tabung elpiji 3 kilogram atau barang bukti lain yang membuat si pemilik restoran menjadi tersangka dalam hal penyalah gunaan gas elpiji 3 kilogram yang di selidiki oleh Polres Sawahlunto, sulitnya mencari saksi dalam tindak pidana dan bungkamnya para tersangka yang melindung-lindungi asal mula dari gas elpiji bersubsidi tersebut maupun berkas perkara yang harus di split dikarenakan satu orang tersangka hanyalah sopir dan dapat di jadikan sebagai saksi dalam perkara lain.

\section{DAFTAR PUSTAKA}

Ade Sofyan Mulazid, Kedudukan Sistem Pengadaian Syariah Dalam Sistem Hukum Nasional Di Indonesia. Kementerian Agama RI, 2012.

C.S.T. Kansil, Christine C.S.T. Kansil, Pokok-pokok Etika Profesi Hukum, Cet. ke 3, Pradnya Paramita, Jakarta, 2006.

Sayyid Sabiq, Fikih Sunnah 5. Cakrawal Publishing, Jakarta, 2009. 
Sri Soedewi Masjchoen Sofwan, Himpunan Karya Tentang Hukum jaminan, Liberty, Yogyakarta, 1982.

Sri Soedewi Masjchoen Sofwan, Hukum Jaminan Di Indonesia Pokok pokok Hukum Jaminan dan Jaminan perorangan, Liberty, Yogyakarta, 2007.

Sutan Remi Syahdeini, Perbankan Islam dan Kedudukannya dalam Tata Hukum Perbankan. Pustaka Ulama Grafiti, Jakarta, 1999, 